\title{
International Criminal Statistics ${ }^{11}$.
}

By KARL O. CHRISTIANSEN, M. A.

University Lecturer in Criminology, Copenhagen.

Among nine subjects which the Social Commission of the United Nations requested the Secretary General to study ${ }^{2}$ ), three were selected for immediate attention, viz., juvenile delinquency, probation, and criminal statistics.

The study of criminal statistics is at present nearing completion, and I shall briefly deal with the following topics falling within its scope: 1) The possibility of international comparisons of criminal statistics. 2) The question of the basis of a crime index. 3) Offences known to the police as the best source of criminal statistics for index purposes. 4) Some of the results of the study. 5) Recommendations with respect to the standardization of criminal statistics.

In 1947 the United Nations sent out a questionnaire to the Member States. The questionnaire included certain questions relating to criminal statistics. Unfortunately it was sent out before the Social Commission requested the Secretariat to undertake a study of criminal statistics and the relevant part of it was not sufficiently detailed and specific. Replies to the questionnaire were received from 35 Member States, and, through the International Iaw Association, also from Finland and Italy.

In the questionnaire information was requested for the tenyear period from 1937 to 1946. However, only a few of the countries were able to supply statistics for the whole period.

Of the innumerable problems which might be the subject of statistical investigation, the interest in the study is focused on the following, considered to be of major importance:

a) The incidence of crime (classified according to groups of offences);

b) Certain major attributes of the offenders, namely:

1) the nature of the offences committed (classified into groups);

2) sex;

3) age, and

4) recidivism.

i) This article is part of a paper, named "International Research in the Prevention of Crime and the Treatment of Offenders , read at the Nineteenth Annual Meeting of the Eastern Sociological Society in New York, April 1949.

2) Third session of the Social Commission from 5 to 28 April 1948. The proposal was later adopted by the Economic and Social Council. 
The information on criminal statistics received from the various countries varied considerably as regards sources, as regards the statistical unit employed, and in fact also as regards the fundamental methods of dealing with some of the most crucial problems of criminal statistics.

\section{International comparisons of criminal statistics.}

Difficulties in international comparisons of criminal statistics arise chiefly because of differences in penal legislation, in criminal procedure, and particularly in administrative practices. Comparisons with respect to the state and structure of crime at a given point of time will, therefore, be impossible. But this does not necessarily hold true to the same extent with regard to comparisons of the trend of crime in different countries during the same period. ${ }^{3}$ ) Such comparisons may be feasible provided that:

(a) No important changes in legislation have occurred in any of the countries during the period of investigation.

(b) No important changes in the administration of the law of any of the countries have occurred during the period concerned.

(a) As regards legislative changes, the situation is as follows:

With respect to the large group of minor offences it is certain that during the war a considerable number of new laws was adopted in most countries. This has in some countries led to a marked increase in the incidence of minor offences. No possibility exists of distinguishing between the part of the increase of crime which is due to legislative changes, and that which is due to other social changes.

As regards major offences, legislative changes of similar importance have not occurred. In most countries the great majority of crimes punishable by the more severe forms of punishment remained almost unchanged throughout the war.

It may therefore be maintained that comparisons of the trend

3) See for instance Augusto Bosco, "Legislation et statistique comparée", Bulletin de l'Institut International de Statistique, Tome XI, Deuxième livraison, 1899, pp. 54, 55 and 63. J.R. B. de Roos, "Consonnes et Voyelles, Communication sur la statistique criminelle , Bull. de l'Inst. Intern. de Stat., Tome XXIII, 2ème livraison, 1928, p. 766. Ernst Roesner, "Die internationale Kriminalstatistik in ihrer methodischen Entwicklung «, Allgemeines statistisches Archiv, 22. Band, 1932, pp. 23-24. Kurt Meyer, „Die unbestraften Verbrechen", Leipzig 1941, p. 78. Stephan Rzepkiewicz, „Observations sur la possibilité des comparaisons des stati stiques criminelles de divers pays", Bull. de l'Inst. Intern. de Stat. Tome XXIV, 2ème livraison, 1930, p. 573. 
of major offences are, from this point of view, less subject to misleading conclusions than is the case with minor offences.

(b) Important changes undoubtedly occurred in the criminal policy of countries which were affected by the war situation. Such changes cannot be demonstrated in detail for all countries, and it is absolutely impossible to measure their effect in quantitative terms. In some countries the statistics show that during the war period there was a greater inclination to proceed to formal conviction in the case of persons whose guilt was established, than before. In Sweden the introduction of the new Penal Code in 1943 was accompanied by certain changes in the system of recording crime,,$^{*}$ ) which has undoubtedly had a considerable influence on the number of offenders registered in that country. But in most cases the changes in criminal policy have been of such a nature that they cannot easily be demonstrated. Generally speaking, it seems prudent to suppose that the changes have led to larger numbers of apprehensions, arrests, summonses, charges, and convictions. This holds true for major as well as for minor offences. In view of the effect of changes of criminal policy on the increasing incidence of recorded crime, the available statistical data can, therefore, not be considered to provide an exact quantitative description of the trend of actual crime, known or unknown. ${ }^{5}$ ) This is of course, even more true in a period of war.

\section{Indices of Crime.}

I should like to illustrate my discussion of the problems of the best basis for a crime index by reference to two charts based on criminal statistics for Denmark.

Graph 1 shows the trend of offences against property as it appears when based on three different statistical units: offences known to the police, persons whose guilt was established, and persons formally convicted. In Denmark, persons whose guilt is established constitute a more comprehensive group than persons formally convicted. Besides persons convicted, this group also comprises persons who were charged with crime, but the charge against whom was withdrawn because of the youthful age of the offender or because of the triviality of the offence.

4) See Sveriges officiella statistik, Rättsväsen, Brottsligheten, 1943, p. 8.

5) See especially V. Verkho, "Kriminalstatistiken och den verkliga brottsligten", Nordisk Tidsskrift for Strafferet, Kbh. 1930, p. 100. 
D EN M A R K

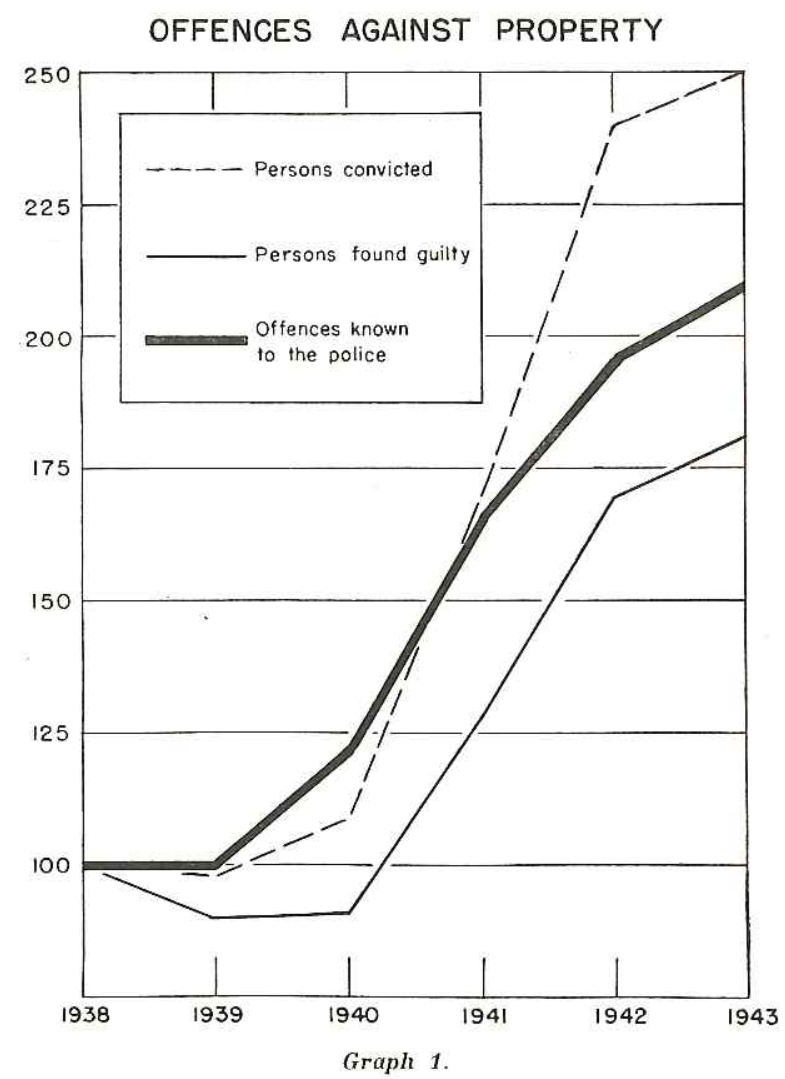

Generally speaking, it may be stated that an upward trend is apparent, regardless of the type of statistical unit used. When a somewhat more detailed comparison is made of the trends shown, however, an interesting fact is revealed. Offences against property known to the police increased more than two-fold, but the total number of persons found guilty did not increase by more than about 80 percent. The increase in crime, however, resulted in a certain reluctance to withdraw charges, and the consequence was that the number of persons convicted increased by 150 percent. In other words, in a period of increasing criminality the attitude of the courts changed in such a way that the increase in the number of convictions more than compensated for the smaller increase 
with respect to the establishment of a person's guilt. The main reason for this is, of course, not merely to be found in a change of attitude among judges themselves. It is closely connected with a similar change in the attitude of other law-enforcing authorities, and, undoubtedly still more important, a similar change in the attitude of society itself towards crime in such a period. Furthermore, it cannot be denied that towards the end of the period the process of establishing the guilt of persons under investigation was affected in a similar way.

When discussing the question of a crime index it may be of interest to examine also the trend of other groups of offences. From Graph 2 it appears that in the case of offences against morality, the three curves showing the trend of crime expressed in different statistical units, again show a similar trend. More detailed examination of the graphs, however, shows similar differences as were apparent from the preceding chart, but an impor-

DEN MARK

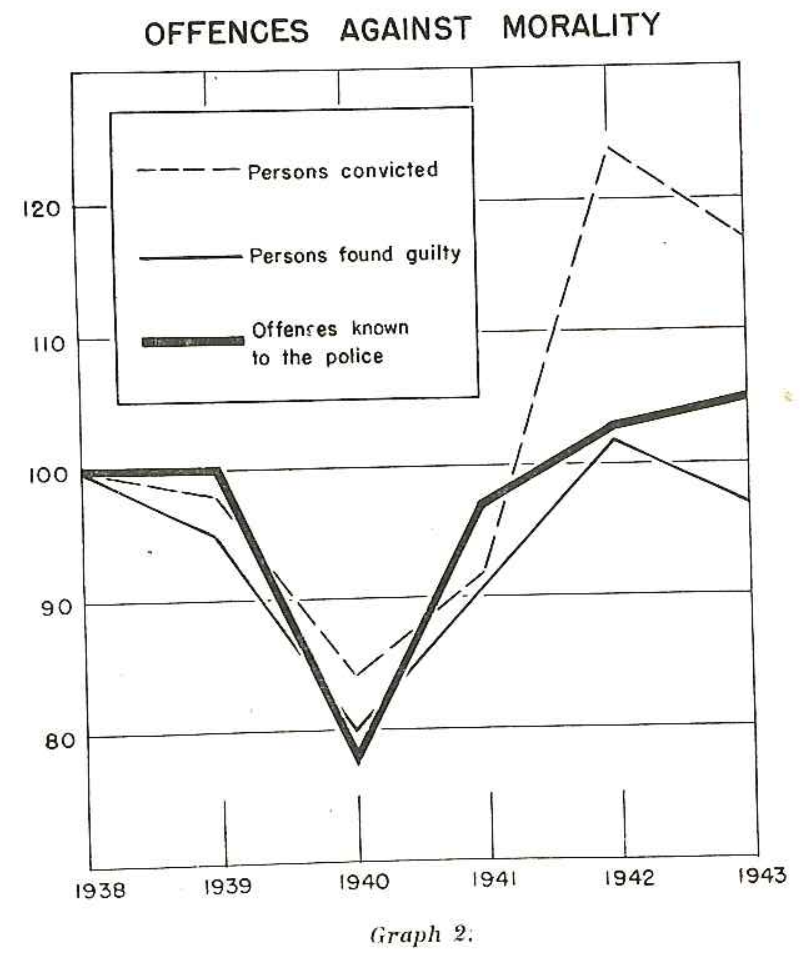


tant point, from the point of view of the present discussion, is brought out. The number of offences against morality known to the police in 1942-43 was the same as in 1938-39. The same holds true for the number of persons found guilty of such offences. But the number of persons convicted increased by about 20 percent. Here one would get quite different results according to the statistical unit used for the investigation. The explanation apparently is - at least in part - that the stronger inclination towards convicting persons under suspicion was quite undifferentiated. It was a general attitude, which may be considered to be an interesting expression of how law-enforcing authorities and society as such react in a period of increasing criminality. It means that conviction is not applied as a rational measure in combating crime.

According to current views, the most important material for the study of the incidence of crime is contained in statistics of offences known to the police. $\left.{ }^{6}\right)$ Even if it must be admitted that certain sources of errors (which can be eliminated in court statistics) exist in the police statistics, the latter are still regarded as presenting the best picture of the true volume and trend of crime. This point of view has been stated very clearly by Thorsten Sellin in an often-quoted statement: "Due to a number of variable elements represented by changes in administrative policies and efficiency, the value of a crime rate for index purposes decreases as the distance from the crime itself in terms of procedure increases. In other words, police statistics, particularly those of crimes known to the police, are most likely to furnish a good basis for a crime index $\left.\ll{ }^{7}\right)$

The statement that offences known to the police are the best available source for studies of the incidence of crime does not

6) See A. von Oettingen, "Die Moralstatistik in ihrer Bedeutung für eine christliche Sozialethik «, Zweite Auflage, Erlangen 1874, p. 443. Georg von Mayr, "Statistik und Gesellschaftslehre", Dritter Band (Moralstatistik mit Einschluss der Kriminalstatistik), Tübingen, 1917, p. 421, Bennet Mead, "Police Statistics «, Annals of the American Academy of Political and Social Science, Vol. CXLVI, 1929, p. 76. Ernst Roesner, op. cit. p. 36. Thorsten Sellin, "Research Memorandum on Crime in the Depression«, Social Science Research Council, Bulletin, 27-30, 1937, p. 65 . Ronald H. Beattie, "The Sources of Criminal Statistics $₫$, Annals of the American Academy of Political and Social Science, Vol. 217, 1941, p. 20. Kurt Meyer, op. cit., p. 10. L. Radzinowicz, "English Criminal Statistics, A Critical Analysis «, The Modern Approach to Criminal Law, London 1945, p. 189. V. Verkko, "Vänner och fiender till kriminalstatistiken «, Nordisk Tidsskrift for Kriminalvidenskab, København 1949, p. 23.

7) Thorsten Sellin, "The Basis of a Crime Index ", Journal of the American Institute of Criminal Law and Criminology, Vol. XXII, 1931-32, p. 346. 
necessarily mean that all difficulties are avoided by relying on such statistics. Not all offences are reported, and among those reported as supposed offences, some are not actually violations of existing laws. It will often be difficult for the police to decide whether a reported offence should be recorded at all; it may even be more difficult to establish whether an offence should be classified as minor or major, or to determine which legal principle was infringed upon by the presumably illegal act. Another, and probably the main, obstacle to arriving at a true picture of the structure of criminality, is the fact that the proportion of offences which in some way or other are brought to the knowledge of the authorities, varies to an almost unlimited extent (from $0 \%$ to $100 \%$ ) as between different kinds of offences. ${ }^{8}$ )

\section{Some results of the study.}

Statistics of offences reported or otherwise known to the police were obtained only for 9 countries. For two of them (Canada and the U.S.A.) the data do not cover the whole of the population but only cities and towns of a certain size. In these cases the absolute figures are related to the corresponding population figures. The figures are, as far as possible, given only for major offences.

The trend of offences known to the police appears from Graph 3. For five of the nine countries (Belgium, Denmark, France, England and Wales, and Iraq) there occurred after the beginning of World War II a more or less considerable increase in the number of offences. For two countries (Finland and the U.S.A.) an increase is noticeable after the war, and for the remaining two (the Union of South Africa and Canada) no great changes have occurred in the volume of crime during this period.

Consequently, it may be stated that the war, and the changes it brought about in social and economic conditions, affected the trend of crime, as depicted in statistics of offences known to the police, differently in various countries. The increase appears early and is considerable in the occupied countries. After an increase in 1941 the curve for England and Wales rises very slowly until 1943, when a new and marked increase starts. In Finland the great increase occurs in 1945. In Iraq the trend is somewhat irregular, but

8) See among others Bennet Mead, op. cit. p. 77. Thorsten Sellin, "The Basis ........, p. 346-48. Jerome Michael and Mortimer J. Adler, "Crime, Law and Social Science", London and New York, 1933, p. 311. L. Radzinowicz, op. cit., p. 191. 
OFFENCES REPORTED OR OTHERWISE KNOWN

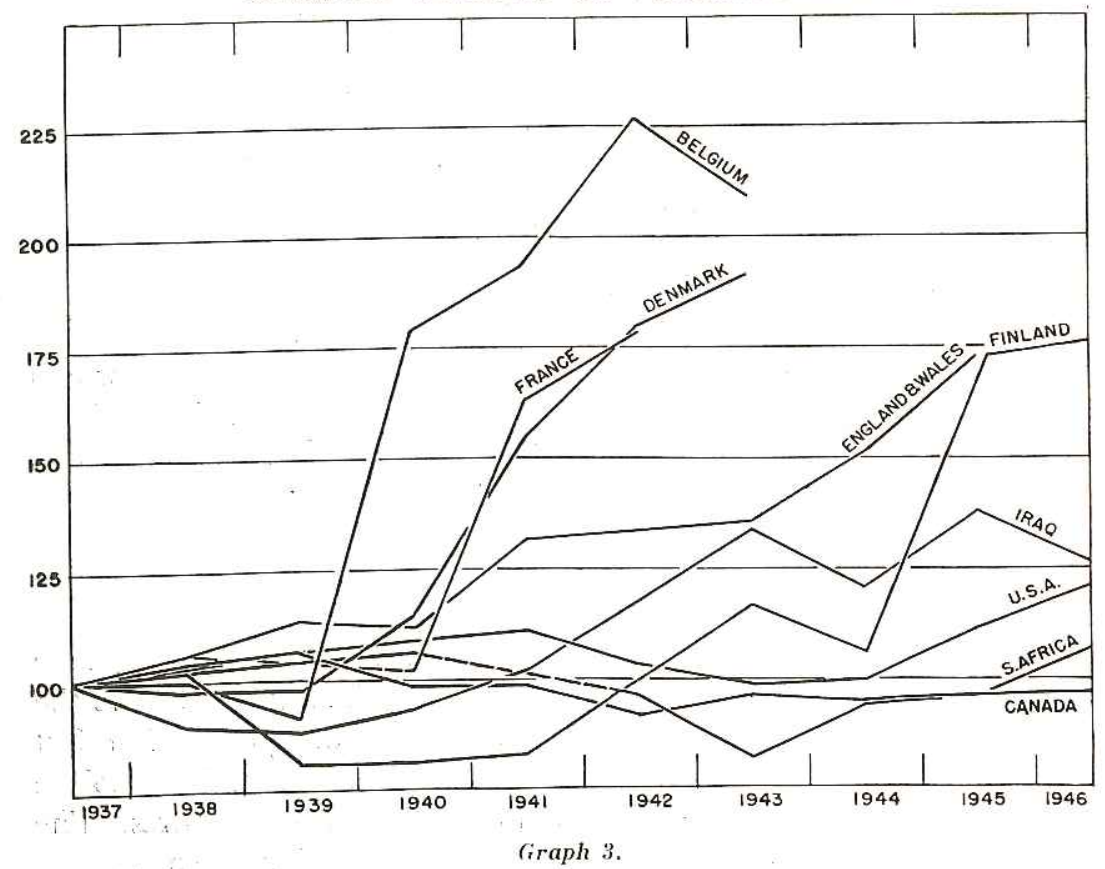

the increase starts in 1942. For the U.S.A. there is, except for a slight increase at the beginning of the period and culminating in 1941, no rise until 1945 and even then it is not very considerable.

On the basis of this material conclusions concerning the possible causes of the variations among the different nations cannot be drawn.

From Graph 4 it would appear that the trend of crime, as depicted in the number of persons whose guilt was established or in the number of persons convicted is, generally speaking, quite similar to the trend of offences known to the police. Most of the countries under investigation experienced a more or less pronounced increase during the war period. Some exceptions from this general statement will be shown in the following figure. Of special interest here is that the increase as regards persons convicted also appears in some of the countries from which no police statistics were available, namely: the Netherlands, Norway, Scotland, Northern Ireland and Australia. It is also interesting to notice that a 


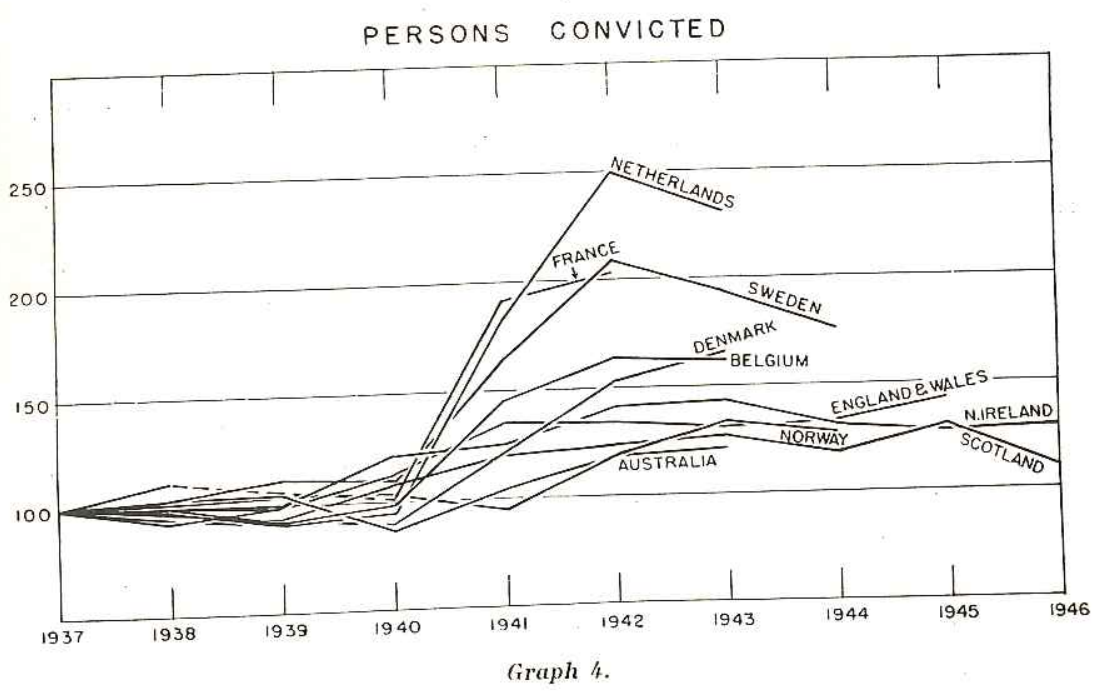

neutral country like Sweden shows as high an increase as most of the occupied countries.

Graph 5 shows the trend of crime (persons found guilty or convicted) for certain countries where there was no considerable increase during the war. In Argentina an increase started before the war, and it does not seem to have been particularly influenced by war conditions. For the other countries no increase appeared. The trend in neutral Turkey was declining from the very beginning of the period; in Turkish statistics offences dealt with according to the penal code form a rather comprehensive group, however,

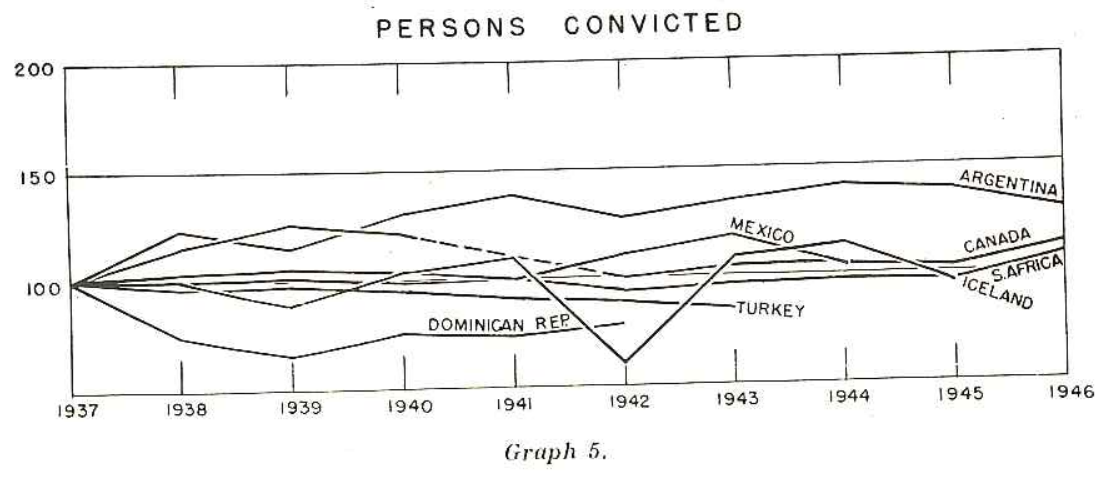


and divergent trends with respect to sub-groups might have tended to off-set each other. There was, in fact, an increase in offences against property, showing an index figure of 134 for 1943, while offences against the person declined, so that the index figure in 1943 was 76.

By depicting the trend of apprehensions, arrests, charges, withdrawals of charges, and convictions a picture of how different societies react to criminality over a given period of time is obtained. The result cannot be considered to be a reliable picture of changes in the volume and nature of real criminality, however. Nevertheless, such a description may be regarded as being of some value from the point of view of criminal policy.

The problems with respect to the sex ratio, the age groups and recidivism also do not permit any generalisations. Analysis of these problems shows once more that they are more complicated than they appear at first glance. None of those three problems can be dealt with separately; they are intimately connected.

The standardization of criminal statistics.

On the basis of this attempt, as on the basis of some of the previous studies in criminal statistics, it becomes quite clear that international comparisons are extremely difficult, if not impossible, to carry out.9) For the United Nations the most important task in this field seems to be the promotion of some standardization of criminal statistics. In 1937 the Joint Commission on Criminal Statistics, consisting of representatives of the International Penal and Penitentiary Commission and of the International Institute of Statistics, published a report under the title "Rules for Drawing Up Criminal Statistics in the Various Countries «. In some respects this important work must still serve as a basis for future endeavours in this field. The Joint Commission resumed its work after the war.

It should however be pointed out, that the importance of some aspects of criminal statistics should be stressed in a slightly different way than was done in the report from the Joint Comission.

Above all, it must be stated that offences known to the police form the best basis for a crime index, and that the governments

9) The history of international criminal statistical comparisons and of the changing views with respect to the possibility of such comparisons is dealt with by Ernst Roesner, op. cit. pp. 17 ff., and $V$. Verkko, "Vänner och fiender .........., pp. $7 \mathrm{ff}$. 
should be encouraged to collect, analyse and publish such data. Furthermore, incidence figures should be given separately for the various offences. On the basis of such statistics it might prove possible to compare on an international basis the incidence of such offences as homicide, aggravated assault and burglary. ${ }^{10}$ ) Much could be learned about the difficulties and how they can be overcome from the work done in the U.S.A. in this specific field. At the same time the hope may be expressed that this country will succeed in extending this important part of its criminal statistics to cover the whole of the nation and its population.

With respect to statistics on juvenile delinquency I am most pessimistic. I doubt whether it is possible for any country to give really reliable information on the volume or the trend of juvenile delinquency, and I consider it absolutely impossible for the near future to make provisions for comparing such data on an international basis.

Statistics on recidivism, in most countries, consist of data on previous convictions of persons convicted in a given year. It would be much more important to undertake the type of follow-up investigations of persons convicted from 5 to 10 or 15 years ago, which was recommended in 1893 by Köbner. ${ }^{11}$ ) Such data are as far as I know only published in the Norwegian criminal statistics. ${ }^{12}$ )

Standardization of criminal statistics will, even if it is only carried out to a very limited extent, require the collaboration of all interest. ed countries and some international organizations. There cannot be any doubt that the United Nations should take some positive action in this field.

\section{Karl. O. Christiansen.}

10) See Thorsten Sellin, „Research Memorandum ........ «, p. 70.

11) 0 . Köbner, „Die Methode einer Rückfallstatistik», Zeitschrift für die gesamte Strafrechtswissenschaft, 13. Band, 1893, pp. $615 \mathrm{ff}$.

12) See for instance Norges offisielle Statistikk, Kriminalstatistikk, 1939-40, Oslo 1942, pp. 2 ff. 